\title{
Good practices in bilingual children
}

\author{
Francesca Cucinotta, Roberta Maggio, Matilde Gagliano, Maria Venuti, Antonella Gagliano* \\ From 70th Congress of the Italian Society of Pediatrics, Joint National Meeting SIP, SICUPP, SITIP \\ Palermo, Italy. 11-14 June 2014
}

Bilingualism is the regular use of more than one language in everyday life $[1,2]$. In our country, $47.2 \%$ of students were born from non-Italian parents [3], and in Europe, bilingualism is even more prevalent: $56 \%$ of the population across all European Union countries is reported being functionally bilingual [4]. So it is critical to understand risks and protective factors specific to the development of bilingual children for clinical and educational reasons.

It is true that linguistic tasks are often performed more poorly by bilingual children than monolinguals $[5,6]$, especially as regards assessment of vocabulary $[7,8]$, picture-naming tasks $[9,10]$, comprehending and producing words $[11,12]$. It is also common among bilingual children who learn Italian as a second language, to have lower skill levels than those of monolinguals, in relation to reading and writing or understanding of texts [13]; but these results cannot be described as a pathological outcome.

In contrast to this pattern, bilinguals at all ages demonstrate better executive control than monolinguals matched in age and other background factors.

In the last decades, many studies showed that the experience of early exposure to two languages, and the constant practice of selecting the target language avoiding intrusions of the non-target language, can improve skills such as selective attention, inhibition and cognitive control with respect to non-verbal tasks. Other benefits also include the early development of metalinguistic ability and better achievements in working memory tasks.

These effects have been found at all stages across the life span, beginning from infancy and toddlerhood, continuing through young adulthood and up to older age [14-17].

Thus, it is a matter of considerable concern with the large and growing dual language population, how to properly recognize normal and abnormal dual language

\footnotetext{
* Correspondence: agagliano@unime.it

UOC di Neuropsichiatria Infantile, Policlinico Universitario G. Martino, Messina, Italy
}

development, and several important implications can be derived from extant developmental and clinical research: a language disorder should be suspected in a dual language child, when the child is reported to be significantly behind in the understanding of both languages, although there has been significant exposure to both languages, and when there are language-based learning problems [18]. While it has been clearly documented that bilingualism does not cause language delay or language disorders [19], the latter are certainly possible in bilingual children. Such possibility should not be easily dismissed and slight delays should not instead be misattributed to the child's bilingual condition even though a more severe delay must be assessed.

Published: 11 August 2014

References

1. Grosjean F: Studying bilinguals. Oxford Linguistics, USA: Oxford University 2008. Ministro dell'Istruzione dell'Università e della Ricerca (MIUR): Gli alunn stranieri nel sistema scolastico Italiano A.S. 2012/2013.

4. European Commission: Special Eurobarometer 243: Europeans and their languages (Executive Summary). Europa Web Portal 2006 [http://ec.europa. eu/public_opinion/archives/ebs/ebs_243_sum_en.pdf].

. Barac R, Balystok E: Bilingual effects on cognitive and linguistic Child Dev 2012, 83:413-422.

6. Bialystok E, Craik FIM, Luck G: Bilingualism: consequences for mind and brain. Trends Cogn Sci 2012, 16:240-250.

7. Bialystok E, Luck G, Peets KF, Yang S: Receptive vocabulary differences in monolingual and bilingual children. Bilingualism: Lanquage and Cognition 2010, 13:525-531.

8. Oller DK, Pearson BZ, Cobo-Lewis AB: Profile effects in early bilingual language and literacy. Appl Psycholinguist 2007, 28:191-230.

9. Bialystok E, Craik FIM, Luk G: Lexical access in bilinguals: effects of vocabulary size and executive control. J Neuroling 2008, 21:522-538.

10. Hernandez EA, Martinez A, Kohnert $K$ : In search of the language switch: an fMRI study of picture naming in Spanish English bilinguals. Brain Lang. 2000, 73:421-431.

1. Ransdell SE, Fischler I: Memory in a monolingual mode: when are bilinguals at a disadvantage? J Mem Lang 1987, 26:392-405.

2. Ivanova P, Costa A: Does bilingualism hamper lexical access in speech production? Acta Psychol (Amst). 2008, 127:277-288. 
13. Bellocchi S, Genesse F: L'apprendimento della lettura in bambini scolarizzati in una seconda lingua: Traiettorie evolutive tipiche e difficoltà. Psicologia Clinica dello Sviluppo 2012, 16:481-506.

14. Kovács ÁM, Mehler J: Cognitive gains in 7-month-old bilingual infants. N Academ of Scien 2009, 106:6556-6560

15. Poulin-Dubois D, Blaye A, Coutya J, Bialystok E: The effects of bilingualism on toddlers' executive functioning. J Exper Child Psychol 2011 108:567-579.

16. Costa A, Hernández M, Sebastián-Gallés N: Bilingualism aids conflict resolution: Evidence from the ANT task. Cognition 2008, 106:59-86.

17. Bialystok E, Craik FIM, Klein R, Viswanathan M: Bilingualism, aging, and cognitive control: Evidence from the Simon Task. Psych Aging 2004, 19:290-303.

18. Toppelberg OC, Collins AB: Language, culture and adaptation in immigrant children. Child Adolesc Psychiatr Clin N Am. 2010, 19:697-717.

19. King K, Fogle L: Raising bilingual children: common parental concerns and current research. Center for Applied Linguistics 2006 [http://www.cal. org/resources/digest/raising-bilingual-children.html].

doi:10.1186/1824-7288-40-S1-A80

Cite this article as: Cucinotta et al:: Good practices in bilingual children. Italian Journal of Pediatrics 2014 40(Suppl 1):A80.

\section{Submit your next manuscript to BioMed Central} and take full advantage of:

- Convenient online submission

- Thorough peer review

- No space constraints or color figure charges

- Immediate publication on acceptance

- Inclusion in PubMed, CAS, Scopus and Google Scholar

- Research which is freely available for redistribution

Submit your manuscript at www.biomedcentral.com/submit 